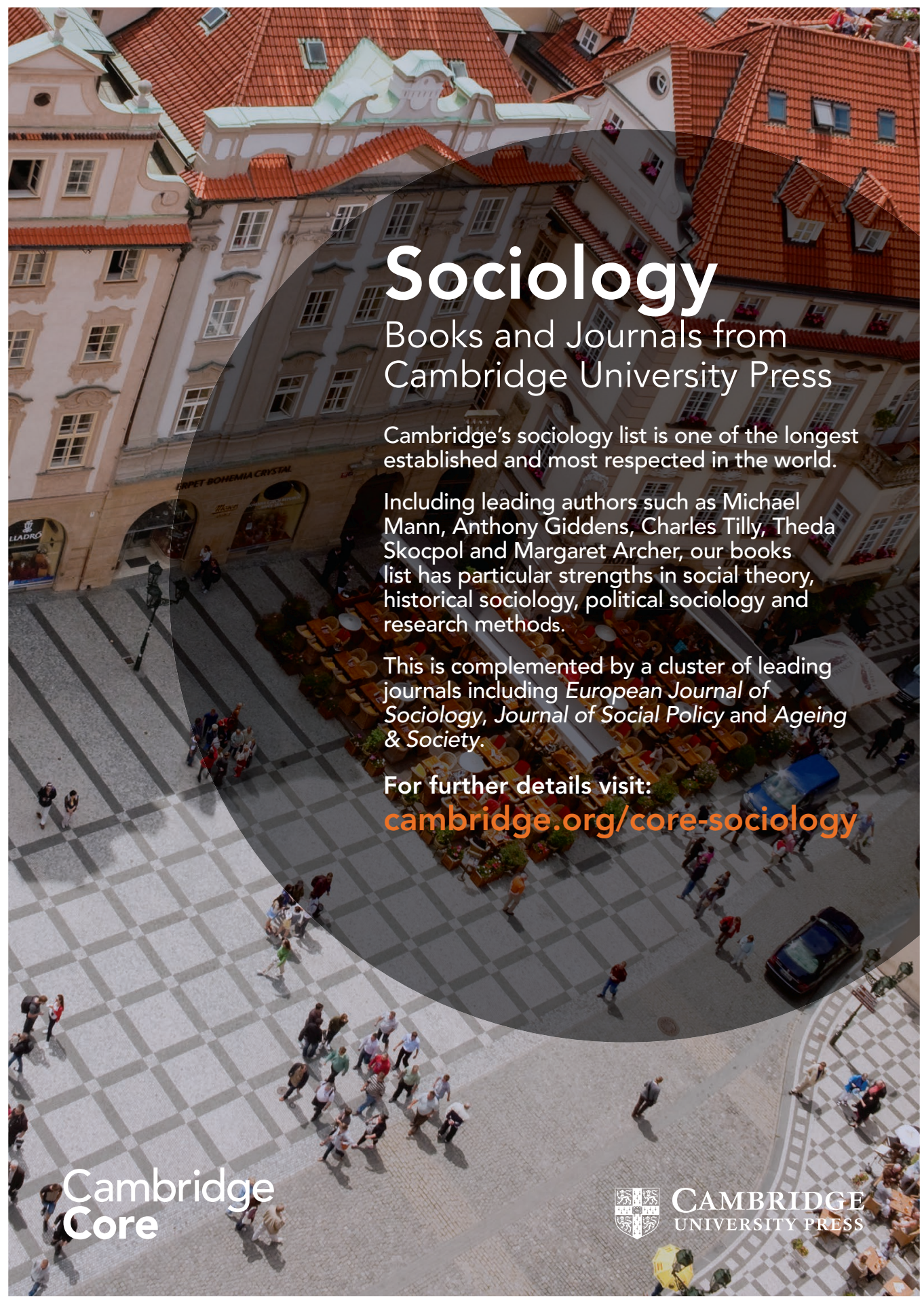



POSTAL SERVICE $_{\circledast}$ (All Periodicals Publications Except Requester Publications)

\section{Publication Title}

Comparative Studies in Society and History

4. Issue Frequency

Every 3 months Jan, Apr, Jul, Oct

7. Complete Mailing Address of Known Office of Publication (Not printer) (Street, city, county, state, and ZIP+4 ${ }^{\circledR}$ )

Cambridge University Press

1 Liberty Plaza

New York, NY 10006

2. Publication Number

\begin{tabular}{|l|}
\hline 2. Publication Number \\
$\qquad 127-080$ \\
4 \\
5. Number of Issues Published Annually
\end{tabular}

3. Filing Date

$10 / 1 / 2021$

6. Annual Subscription Price

$\$ 398.00$

\section{Contact Person}

Nina lammatteo

Telephone (Include area code)

212-337-5004

8. Complete Mailing Address of Headquarters or General Business Office of Publisher (Not printer)

Cambridge University Press

Edinburgh Building, Cambridge CB2 2RU, England

9. Full Names and Complete Mailing Addresses of Publisher, Editor, and Managing Editor (Do not leave blank)

Publisher (Name and complete mailing address)

Cambridge University Press

1 Liberty Plaza

New York, NY 10006

Editor (Name and complete mailing address)

Paul Christopher Johnson and Geneviève Zubrzycki, 1007 East Huron, The University of Michigan, Ann Arbor, MI 48109-1690

Managing Editor (Name and complete mailing address)

10. Owner (Do not leave blank. If the publication is owned by a corporation, give the name and address of the corporation immediately followed by the names and addresses of all stockholders owning or holding 1 percent or more of the total amount of stock. If not owned by a corporation, give the names and addresses of the individual owners. If owned by a partnership or other unincorporated firm, give its name and address as well as those of each individual owner. If the publication is published by a nonprofit organization, give its name and address.)

\begin{tabular}{l|l}
\hline Full Name & Complete Mailing Address
\end{tabular}

Society for Comparative Study of Society and History University of Michigan

1007 East Huron

Ann Arbor, Ml 48109-1690

11. Known Bondholders, Mortgagees, and Other Security Holders Owning or Holding 1 Percent or More of Total Amount of Bonds, Mortgages, or Other Securities. If none, check box

$\rightarrow \mathbb{X}$ None

\begin{tabular}{l|l}
\hline Full Name & Complete Mailing Address \\
\hline & \\
\hline & \\
\hline & \\
\hline
\end{tabular}

12. Tax Status (For completion by nonprofit organizations authorized to mail at nonprofit rates) (Check one)

The purpose, function, and nonprofit status of this organization and the exempt status for federal income tax purposes:

$\square$ Has Not Changed During Preceding 12 Months

$\square$ Has Changed During Preceding 12 Months (Publisher must submit explanation of change with this statement) 


\begin{tabular}{|c|c|c|c|c|}
\hline \multirow{4}{*}{$\begin{array}{l}\text { b. Paid } \\
\text { Circulation } \\
\text { (By Mail } \\
\text { and } \\
\text { Outside } \\
\text { the Mail) }\end{array}$} & (1) & $\begin{array}{l}\text { Mailed Outside-County Paid Subscriptions Stated on PS Form } 3541 \text { (Include paid } \\
\text { distribution above nominal rate, advertiser's proof copies, and exchange copies) }\end{array}$ & 61 & 59 \\
\hline & $(2)$ & $\begin{array}{l}\text { Mailed In-County Paid Subscriptions Stated on PS Form } 3541 \text { (Include paid } \\
\text { distribution above nominal rate, advertiser's proof copies, and exchange copies) }\end{array}$ & 0 & 0 \\
\hline & (3) & $\begin{array}{l}\text { Paid Distribution Outside the Mails Including Sales Through Dealers and Carriers, } \\
\text { Street Vendors, Counter Sales, and Other Paid Distribution Outside USPS }{ }^{\circledR}\end{array}$ & 101 & 109 \\
\hline & (4) & $\begin{array}{l}\text { Paid Distribution by Other Classes of Mail Through the USPS } \\
\text { (e.g., First-Class Mail }{ }^{\circledR} \text { ) }\end{array}$ & 0 & 0 \\
\hline \multicolumn{3}{|c|}{ c. Total Paid Distribution [Sum of 15b (1), (2), (3), and (4)] } & 162 & 168 \\
\hline \multirow{4}{*}{$\begin{array}{l}\text { d. Free or } \\
\text { Nominal } \\
\text { Rate } \\
\text { Distribution } \\
\text { (By Mail } \\
\text { and } \\
\text { Outside } \\
\text { the Mail) }\end{array}$} & (1) & Free or Nominal Rate Outside-County Copies included on PS Form 3541 & 0 & 0 \\
\hline & $(2)$ & Free or Nominal Rate In-County Copies Included on PS Form 3541 & 0 & 0 \\
\hline & (3) & $\begin{array}{l}\text { Free or Nominal Rate Copies Mailed at Other Classes Through the USPS } \\
\text { (e.g., First-Class Mail) }\end{array}$ & 0 & 0 \\
\hline & (4) & Free or Nominal Rate Distribution Outside the Mail (Carriers or other means) & 0 & 0 \\
\hline \multicolumn{3}{|c|}{ e. Total Free or Nominal Rate Distribution (Sum of 15d (1), (2), (3) and (4)) } & 0 & 0 \\
\hline \multicolumn{3}{|c|}{ f. Total Distribution (Sum of $15 \mathrm{c}$ and $15 \mathrm{e}$ ) } & 162 & 168 \\
\hline \multicolumn{3}{|c|}{ g. Copies not Distributed (See Instructions to Publishers \#4 (page \#3)) } & 30 & 36 \\
\hline \multicolumn{3}{|c|}{ h. Total (Sum of $15 f$ and $g$ ) } & 192 & 204 \\
\hline \multicolumn{3}{|c|}{$\begin{array}{l}\text { i. Percent Paid } \\
\text { (15c divided by } 15 f \text { times } 100 \text { ) }\end{array}$} & $100 \%$ & $100 \%$ \\
\hline
\end{tabular}

* If you are claiming electronic copies, go to line 16 on page 3 . If you are not claiming electronic copies, skip to line 17 on page 3. 


\section{a. Paid Electronic Copies}

b. Total Paid Print Copies (Line 15c) + Paid Electronic Copies (Line 16a)

c. Total Print Distribution (Line 15f) + Paid Electronic Copies (Line 16a)

d. Percent Paid (Both Print \& Electronic Copies) (16b divided by $16 \mathrm{c} \times 100$ )

\I certify that $50 \%$ of all my distributed copies (electronic and print) are paid above a nominal price.

17. Publication of Statement of Ownership

If the publication is a general publication, publication of this statement is required. Will be printed

in the January issue of this publication.

18. Signature and Title of Editor, Publisher, Business Manager, or Owner

I certify that all information furnished on this form is true and complete. I understand that anyone who furnishes false or misleading information on this form or who omits material or information requested on the form may be subject to criminal sanctions (including fines and imprisonment) and/or civil sanctions (including civil penalties). 


\section{COMPARATIVE STUDIES IN SOCIETY AND HISTORY}

ISSN 0010-4175

Founded by Sylvia L. Thrupp

Comparative Studies in Society and History is a forum for new research and interpretation concerning problems of recurrent patterning and change in human societies through time and in the contemporary world. It sets up a working alliance among specialists in all branches of the social sciences and humanities. Review articles and discussions bring readers into touch with current findings and issues.

\section{NOTES FOR CONTRIBUTORS}

CSSH welcomes submissions. Essays should be written in such a way that complex issues are made intelligible and appealing to erudite readers who are not specialists in the subject under investigation. The editors prefer essays that are concise and will not accept for review essays over 14,000 words, including notes, references, and abstracts. Include an abstract of no more than 250 words that gives a concise description of the hypothesis, methodology, key sources, and conclusions. Include a list of up to ten keywords, expressing the precise content of the manuscript. Authors of essays accepted for publication must secure and submit permissions to reproduce any photographs or other illustrations and tables.

For the procedures for preparing and submitting manuscripts for review, go to https://cssh.lsa.umich.edu/guidelines/

Hard copies of correspondence may be sent to:

David Akin, Managing Editor

Comparative Studies in Society and History

University of Michigan

6503 Haven Hall

Ann Arbor, MI 48109-1045

USA

Please do not post materials to us by a means that requires a signature for delivery. 


\section{COMPARATIVE STUDIES IN SOCIETY AND HISTORY}

Editorial Foreword

Moral Exemplarity and the Icons of Fascism

Caroline Humphrey The Slippages of Exemplary Action: The Case of Ataman Semenov

Hannah Malone The Fallen Soldier as Fascist Exemplar: Military Cemeteries and Dead Heroes in Mussolini's Italy

AdAm ReED Sympathy for Oswald Mosley: Politics of Reading and Historical Resemblance in the Moral Imagination of an English Literary Society

\section{Ordinary Fascism}

PaOlo HeYwood Ordinary Exemplars: Cultivating "the Everyday" in the Birthplace of Fascism

Stephen Gundle Mussolini between Hero Worship and Demystification: Exemplary Anecdotes, Petite Histoire, and the Problem of Humanization

Fascist Revivals, Neofascism, and the Youth

AgnieszKa PasieKa "Tomorrow belongs to us": Pathways to Activism in Italian Far-Right Youth Communities

NitZan Shoshan Hitler, for Example: Registers of National Socialist Exemplarity in Contemporary Germany

Francisco Ferrándiz Francisco Franco Is Back: The Contested Reemergence of a Fascist Moral Exemplar

\section{Plague Narratives}

Michael Meng Writing on Death: Plague Narratives. 